\title{
The Unintended Consequences of UNESCO's Documentary Heritage Program: Shaming without Naming
}

\author{
Ryoko Nakano
}

School of International Studies, Faculty of Law, Kanazawa University, Japan

Corresponding author. E-mail: rnakano@staff.kanazawa-u.ac.jp

https://doi.org/10.12982/CMUJASR.2018.0006

\begin{abstract}
UNESCO operates the documentary heritage program, Memory of the World, in accordance with its mission of promoting international peace and cooperation. However, the creation of 'world significant' documentary heritage can sow the seed of international conflicts. This article examines how UNESCO is trapped in a pitfall whereby documentary heritage functions to shame its member states without naming. While 'naming and shaming' is a popular tactic to condemn the unethical conduct of states, shaming can occur without naming. This article highlights the political aspect of UNESCO's heritage listing by focusing on the domestic processes in which the actors outside heritage construction perceive and react to the heritage promotion. In particular, the case of Japan helps to showcase this problem. At the end, this article argues that UNESCO's documentary heritage program is under severe criticism and vigorous scrutiny because heritage has a socio-political dimension that the organization cannot control.
\end{abstract}

Keywords: UNESCO, Naming and shaming, Documentary heritage, Japan, Memory

\section{INTRODUCTION}

Raped while dying

And still no arrests?

How come, Chief Willoughby?

(Three Billboards outside Ebbing, Missouri, 2017) 
Losing a beloved one to rape and murder causes a strong sense of anger and heartbreak. The pain of bereaved families is so strong that they may have a desire for revenge, but how and to what extent should this be accepted? Three Billboards outside Ebbing, Missouri, nominated for the 2017 Academy Award for Best Picture, brings this question to the fore in a subtle but striking manner. The main protagonist, Mildred Hayes, a mother whose daughter was raped and murdered on the road, decided to post some questions on three billboards outside the town. The words with a question mark do not directly accuse the police chief, but everyone in town understands that it is meant to shame the lack of police actions to catch the criminal perpetrator.

'Naming and shaming' is a popular tactic to change the behavior of targeted actors through publicly exposing the violations of normative standards and legal institutional frameworks (Friman, 2015). Nongovernmental organizations, news media, and international organizations can use this tactic to gain public support to condemn the unethical conducts of states, such as human rights violations (Risse et al., 1999; DeMeritt, 2012). Discourse is important because it creates meaning, knowledge and even 'reality' (Van Dijk, 2003). Public accusation to put the immoral conduct in the spotlight may work when it shapes the international public discourse on what should and should not be allowed.

However, shaming can take place even without the act of naming. Just showing a symbol of critical historic events is sufficient to cause a sense of shame for viewers who are attached to the events in some way. Statues, monuments, signs, and visual images can cause tensions and contestations in society when viewers recognize a political motive behind those objects and buildings. Amongst them, what is called heritage, and the promotion of it, also has a socio-political impact because its existence is deeply embedded in a social context (Smith, 2006). Precisely for this reason, conflicts over heritage are heavily politicized over the decisions of international heritage listings, most notably UNESCO's World Heritage lists (Meskell, 2018). Despite UNESCO's noble mission to create 'peace in the minds of men and women', its heritage programs unintentionally function as a place to intensify tensions and conflicts among nations and states.

This brief article highlights such a paradox by focusing on the way in which UNESCO's listing of documentary heritage invites sharp criticism and reactions from its member state, Japan. By no means is this 
the only case to show the paradox, as Palestine's nomination of the 'Liberation graphics Collection of Palestinian Posters' caused a controversy in Israel and beyond (Houdek, 2016). However, the case of East Asia is an important one that significantly influences the selection process of UNESCO's documentary heritage program. To examine how UNESCO's decision on the heritage listing caused a controversy in Japan, I use public speeches, news articles, and opinion papers related to the subject as empirical data.

The structure of this article is as follows. First, I briefly sketch out UNESCO and its Memory of the World (MOW) program. Second, I explain how UNESCO's inscription of the 'Documents of Nanjing Massacre' in its MOW Register in 2015 invited fierce criticism from Japan. Third, I provide analysis and discussion on the ways in which the Japanese government and media responded to UNESCO's inscription. In conclusion, I summarize the findings of this article and give an alert that UNESCO's heritage programs can be a place to reinforce tensions and contestations against its original intention for enhancing international cooperation.

\section{UNESCO AND ITS DOCUMENTARY HERITAGE PROGRAM}

UNESCO is known as an international cultural organization whose mission is to promote international peace. Founded in the aftermath of World War II, it has a strong moral orientation towards the construction of human solidarity and peace from below, as stated in the preamble to its constitution, "Since wars begin in the minds of men, it is in the minds of men that the defenses of peace must be constructed" (UNESCO, 1945). As the heir of the International Institute of Intellectual Cooperation under the League of Nations, UNESCO is also known as an expert organization. Scientists, writers, artists and intellectuals from different countries and cultures are involved in the scientific, educational and cultural activities undertaken by the organization. In cooperation with other expert organizations and local counterparts, UNESCO has launched a number of programs, many of which have a global impact (Duedahl, 2016).

Memory of the World (MOW) is one of those programs started in 1992. Like World Heritage, the original aim is to protect precious historical documents from destruction (Harvey, 2007). Its scope has expanded to include other aims such as promoting universal access and public awareness of the world's significant documents as the 
common heritage of humankind (UNESCO, 2002). This is an expertinitiated program as the General Guidelines to Safeguard Documentary Heritage has been prepared and updated mostly by nongovernmental expert institutions, such as the International Federation of Library Associations (UNESCO 1995; 2002). In the MOW program, the meaning of 'documents' does not literally limit to documents but includes recorded audiovisual materials. They are defined as "moveable, made up of signs/codes, sounds and/or images, preservable (the carriers are non-living), reproducible and migratable, and the product of a deliberate documenting process" (UNESCO 2002). Those objects are subject neither to World Heritage that aims to ensure the protection and preservation of sites, monuments and landscapes, nor to Intangible Cultural Heritage that targets traditions or living expressions passed on from generations to generations. To increase international awareness of documentary heritage, MOW has developed public registers that list up materials of 'world significance' (UNESCO 2002). Although there are national and regional registers, the international one is the most visible for its attachment to UNESCO in general.

MOW has a unique feature that reflects the time of the postCold War era. First, MOW welcomes civil society initiatives. While World Heritage and Intangible Cultural Heritage accept nominations only from the national commissions for UNESCO, MOW allows any person or organization to nominate the documents for inscription in the register. Second, MOW has an expert-orientation with little space for state's interference. Because MOW has not been built by any conventions or treaties, it is the International Advisory Committee (IAC), which consists of fourteen experts in archival and library studies, to assess nominations and make a recommendation to UNESCO's Director-General. UNESCO's Director-General, the final decision-maker over the MOW Registers, conventionally endorses the recommendation by the IAC. These features are supposed to make the program less political and more neutral.

For IAC to carry out its duty of assessment, the MOW Guidelines set criteria on authenticity, uniqueness, world significance, rarity and integrity, the existence of threats, and a management plan. Those reference points are neither to interpret the meaning of documents and audiovisual records nor to evaluate the truthfulness of what they suggest or signify. However, a nomination form, to which IAC refers, often contains an interpretive description of the nominators about 
the materials. For instance, the University College London (2016) that retains the George Orwell Archive wrote in its nomination that Orwell's writing

...had a profound influence on human thought in all parts of the world, an influence that remains potent today ... It is rare to find serious reviews analysing current events even now, in the first quarter of the $21^{\text {st }}$ century, with no mention of Orwell or his ideas.

As this description indicates, nominations can be made with slight exaggeration without hard evidence, though it can still sound neutral, reflecting the perspective of nominators who understand the significance of the documents. Besides, after the successful entry into the MOW Registers, the local and national media tend to describe the inscription as proof that the nominators' evaluation is internationally accepted. The Guardian, a UK newspaper, reported, “UNESCO's selectors had recognised the "world significance and outstanding universal value' of Orwell's writings" (Flood, 2018). While this sentence implies that the content of Orwell's writings is recognized as significant and universal, either IAC nor UNESCO make such a direct claim. In theory, the value of documents and historical interpretation are virtually separated when IAC assesses the nomination. However, the nomination form includes the language of constructing the meaning and value of the content that makes documents heritage, and the media refer to such language and connect it to the universal norm of UNESCO.

To create a list of global documentary heritage, MOW also reflects the normative and mnemonical trend in the liberal international order, that is, the reshaping of memories from a human rights perspective. For example, World Heritage Lists has included sites of slavery and atrocity, ranging from Auschwitz-Birkenau (inscribed in 1979) to the Atomic Bomb Dome (1996), and to the Stone Town of Zanzibar (2000). Those negative heritage sites provide an opportunity for learning lessons from the past, and hence, giving a positive didactic influence (Logan and Reeves, 2009). In a similar way, MOW Registers have gained a number of documentary collections related to human rights violation at the turn of the millennium. In 2003, Human Rights Archive of Chile', listed in the MOW Register, contains the records of 3,877 human rights violations that were investigated by the Truth and Reconciliation Commission after the military dictatorship from 1973 
to 1989. Argentina's 'Human Rights Documentary Heritage 1976-1983 - Archives for Truth, Justice and Memory in the Struggle Against State Terrorism' was included in the Register in 2007 and Paraguay's 'Archives of Terror' in 2009.

Compared to World Heritage, MOW has a small scale and is less known to the public. Nevertheless, state and non-state actors aim to use this program to promote their own heritage to the world (Nakano, 2018). While the documents such as the Diaries of Anne Frank and the Magna Carta are already famous worldwide, many other documents would not be known to the public without any platform for publicity. Getting listed in MOW Registers provides an opportunity for international recognition and UNESCO's credibility. For its social and economic impacts, local and national communities promote their heritage, hoping to rekindle a sense of pride and attachment to the historical documents and to gain external support and increase tourism. As the functions of heritage and heritage listings become widely recognized and shared in international society, East Asian countries have also become keen to engage in UNESCO's heritage programs.

\section{UNESCO'S 2015 HERITAGE LISTING AND JAPAN'S RESPONSE}

UNESCO announced the inscription of 48 documentary or audiovisual collections as world significant heritage in 2015. Among them, two entries from Japan, 'Return to Maizuru Port-Documents Related to the Internment and Repatriation Experiences of Japanese (1945-1956)' and 'Archives of Tōji Temple Contained in One-Hundred Boxes", were successfully inscribed in the MOW Register. However, the inscription of China's nominated item, the 'Documents of Nanjing Massacre', gained much bigger public attention in Japan.

On October 2 and 13, 2015, Japan's Chief Cabinet Secretary Yoshihide Suga (2015a, 2015b) made two main points regarding this case. First, Japan considered China's nomination as a political abuse of UNESCO. He argued that Japan repeatedly asked China for reconsidering the nomination since 2014, but in vain. China's unwillingness to discuss this issue with Japan was against the spirit of moving forward for cooperation. Second, UNESCO may lack transparency and fairness in operating the MOW program. He suggested that UNESCO should carry out its mandate to promote international cooperation. If not, Japan would consider a suspension of its financial contribution. 
Suga's strong critique of China and UNESCO was echoed by the ruling party, the Liberal Democratic Party of Japan (LDP), the media, and historical revisionists in Japan. LDP adopted a resolution that strongly opposed China's 'political use of UNESCO' and demanded UNESCO's neutrality over political issues (Sankei, 2015a). The Sankei media company, renowned for its far-right political stance, has published a number of reports and opinion articles that criticizes UNESCO's inscription. Its magazine Seiron [Sound Arguments] (2015) invited historical revisionists to feature this issue with a sensational description that the inscription was Japan's 'diplomatic defeat in the history war'. In this issue, Nobukatsu Fujioka (2015) argued that some of the films and photos included in the Documents of Nanjing Massacre' were fake. Shiro Takahashi (2015) and Kenichi Ara (2015) deplored that Japan was not able to prevent China and UNESCO from tarnishing Japan's international image and status. The issue was also followed by the center-left magazine Sekai (2016) in a style of forum among experts on this subject. Although the tone was softer, its critique was placed on China and UNESCO as well.

The critics of UNESCO also voiced concern over the possibility that another WWII-related archival collection would be included in the MOW Register. A group of Chinese archival institutions already had nominated 'Archives about 'Comfort Women' for Japanese Troops' in the 2014/2015 cycle. After it failed, the Chinese institutions were reported to join a Korea-based civil society network to nominate a more extended documentary collection under the name of the 'Voices of Comfort Women' in the 2016/2017 cycle. When it materialized, Suga (2016) argued that the nomination from Korea was against UNESCO's spirit of mutual understanding and cooperation. Hiroshi Yamada, an LDP member, also asserted at a public meeting in the House of Councillors of Japan (2016) that the comfort women materials included the paintings of the former comfort women, one of which depicted the imaginary punishment of the Japanese emperor. He suggested that such a collection should come under more scrutiny. Sankei news (2016a) also argued that any efforts to inscribe the comfort women documents in UNESCO should be prevented because they were suspected to include untruthful oral testimonies.

What followed was Japan's efforts to promote an institutional reform of MOW. At UNESCO's General Conference in November 2015, the Japanese education minister urged UNESCO's member states 
to 'discuss among each other for reforms in order to improve governance and transparency' of the MOW program' (Hase, 2015). Japan's government encouraged the IAC members to reconsider the program's selection process and made a proposal for the creation of an inter-state committee, a requirement for expert examination of submitted documents and a revised process for selecting the IAC's members (Sankei, 2016b).

In Sankei newspaper, the target of criticism mostly rested on bureaucratic institutions such as the Ministry of Foreign Affairs (MOFA) and the Ministry of Education, Culture, Sports, Science and Technology (MEXT), not the government under Shinzo Abe. For example, it said,

What are the MOFA and MEXT doing? Prime Minister Abe should not rely on UNESCO to do an important task for the creation of an institutional framework to prevent any political abuse. Rather, he should take an initiative in pushing this agenda with the strong leadership of the Prime Minister's office. (Sankei, 2016c).

Moreover, Sankei's opinion makers, Shiro Takahashi, a professor of education and a historical revisionist who attended UNESCO's meetings due to his close connection with Abe, and Yoshiko Sakurai, a freelance journalist and TV presenter, also deplored the lack of Japanese engagement in UNESCO's MOW program, as well as the experts involved in UNESCO's MOW program. Takahashi (2016) wrote that Japan was outside the international archivist networks and that no Japanese was regrettablya current member of IAC. He described that the report of the sub-committee reflected the Chinese view and the very fact that Japan could not interfere in the MOW's decision making was a failure of Japanese diplomacy. Japan's incapability of preventing the inscription was considered a loss of its international influence vis-à-vis China. Sakurai (2016) directly criticized the Japanese collaborators within a Korean group that nominated comfort women documents, as well as one of the founders and advisor of MOW, Ray Edmondson, as a non-elected archivist who encouraged such efforts. She went further to suggest that due to his secret connection with the Korea-based civil society group, Edmondson was like Harold John Timperley, who served as an advisor for the publicity department of the Chinese Nationalist Party during WWII to propagate forged information on what happened in Nanjing. 
From October 2016 to December 2017, the Japanese government suspended its financial contribution to UNESCO twice, putting pressure on the organization to revise the selection process in the manner outlined in Japan's proposal. During this period, the review of MOW program took place in UNESCO. Sankei's editor Noboru Okabe (2017) criticized MOFA while encouraging the government to press for a fundamental change in the MOW. His editorial criticized the lack of action by MOFA against the naming and shaming of Japan from other countries and summoned MOFA's courage to engage in 'international public communications within a systemic framework of historical recognitions based on facts'. Sankei (2017) continued to argue, "to protect Japanese honor, the government should communicate a clear, fact-based message to international society".

In December 2017, a review report on MOW came out in favor of Japan, saying that mediated dialogue between the concerned parties should be required for any 'questioned nomination' (UNESCO, 2017). As a result, the assessment of the 'Voices of Comfort Women' was suspended. The Japanese government finally made payment of the assessed contribution to UNESCO at the end of 2017. To further e nsure the implementation of MOW's reform, Japan has continued its diplomatic efforts. When Japanese Prime Minister Shinzo Abe met the new Director-General of UNESCO Audrey Azoulay in October 2018, he emphasized the importance of MOW reforms. He also sent a special envoy to UNESCO to ensure acknowledgment of the Japanese point of view in February 2019 (Sankei, 2019).

\section{DISCUSSION AND ANALYSIS: SHAMING JAPAN}

UNESCO's inscription of the 'Documents of Nanjing Massacre' invited substantial reactions from the Japanese government, LDP, and the rightwing nationalistic media. Without naming Japan, the inscription is perceived as shaming Japan. Two types of shame were provoked. The first is directly related to the Documents of Nanjing Massacre where by past allegations of brutal Japanese conduct are documented. Although neither China nor UNESCO directly criticized Japan's past wrongdoings in World War II, UNESCO's recognition of the 'massacre' documents as 'world significant' heritage heightened a sense of Japan's ontological insecurity. The second comes from the social effect of having UNESCO's credential associated with China's historical narrative. This is considered a symbolic result of the weakness of Japan's diplomatic, political, and cultural power. 
On the first point, China's nominated documents, packaged under the label of 'Nanjing Massacre', unfairly provoked a sense of shame in Japan. They include oral testimonies that exaggerate the number of Chinese victims under the Japanese invasion, as well as photos taken in a place irrelevant to Nanjing. While those documents and other materials have been used as historical evidence of the Chinese official narrative of the war, their reliability and neutrality have not been accepted in Japan. The Japanese conservative government persistently tends to put more emphasis on historical accuracy and avoidance of any simplification that Japan was the same as Nazi Germany. To prevent the accrual of such deep-seated stigma in international society, Japan refuses to give an unconditional apology to other Asian countries for what occurred during World War II (Zarakol, 2010; 2011). Against this background, the Japanese government fears that the promotion of a politically and historically biased perspective on the supposed 'Massacre', and China's historical narrative associated with it, will spread across the world through UNESCO's heritage program. In addition, it is worried about a possibility that the Korean historical narratives on 'comfort women' as sex slaves will be disseminated in the same way. Already, Japan has been sensitive to the spread of the comfort women issues outside East Asia and want to prevent any further internationalization of what the Japanese government considers distorted, ahistorical views of this contested issue. (Yamaguchi et al., 2016).

The second type of shame is related to the current international status of Japan in the world. The very fact that Japan was not able to prevent UNESCO from inscribing Chinese documents pointed out the weakness of Japan's diplomatic, political and cultural power. The critiques of Japanese bureaucratic institutions such as MEXT and MOFA reflected the view that Japan has not done enough as a responsible international player. This sentiment was also associated with the naïve Japanese expectation for UNESCO and its associated experts to take a completely neutral stance. A comparison between Japan's weak engagement with the MOW as compared to China's further deepened a sense of declining Japanese influence vis-à-vis China.

The rightwing newspaper and magazines, published by Sankei media company, and related opinion-makers are powerful in provoking 
the second type of shame. They attack the ministries for not doing their job to defend Japanese national interests and its international position. This is part of their wide coverage of Rekishi-sen (History Wars) in East Asia. They discuss what Korea and China have done to shame Japan, as well as how Japan is unprepared and unable to counterattack such actions. In their view, inaccurate and exaggerated information about what Japan did during WWII has spread across the globe because of the incapability of Japan's public diplomacy and strategic communications. The right-wing media and historical revisionists thus point to Japan's weak-kneed diplomacy and inability to counteract the unfair operations of UNESCO.

With the media attacking past administrations and ministries, the Abe government gained sufficient political leverage to strengthen the power of the Prime Minister's office in putting pressure on UNESCO to change the MOW selection process in favor of Japan. As the Japanese government may want to claim, the impact of its response may benefit the legitimacy and transparency of the MOW program. However, it will also work to prevent UNESCO from assessing any documents in controversy without obtaining an agreement with the related parties such as was the case with Japan.

\section{CONCLUSION}

In this paper, I addressed the puzzle of why UNESCO functions in the opposite direction to its mission for promoting international peace. UNESCO launched a documentary heritage program with good-will and experts' initiatives. It was intended to save precious historical documents from destruction and harness a spirit of cooperation through developing global archival memories. However, the act of listing documents and audiovisual records of issues of contested historical accuracy as world significant heritage unintentionally creates controversies and intensifies tensions among nations and states. Even without the direct naming of targeted actors, the promotion of documents that point to their misconduct under the heading of heritage is a symbolic act to shame them. Because UNESCO is respected as an internationally renowned organization, it cannot avoid repercussions from its members states and people once its actions are recognized as one-sided. The processes through which UNESCO's documentary heritage program caused controversies in Japan were complex. It was not just the Japanese government but the domestic right-wing media 
that extensively discussed the importance of taking action. The target of criticism was not only China and UNESCO but Japanese ministries and bureaucrats that had been involved in UNESCO's heritage programs. Along with the media criticism, the Japanese government gained political leverage domestically in persistently pressuring UNESCO to change the selection system. The connection between the Japanese government and the right-wing media is beyond the scope of this paper. What I want to emphasize is that UNESCO's documentary heritage program came under severe criticism and vigorous scrutiny because heritage has a socio-political dimension that the organizationcannot control.

Those observations point back to the film, Three Billboards outside Ebbing, Missouri, which demonstrates the indirect shaming of a targeted actor without naming him. Moreover, the concomitant stories after the release of the film gives an additional lesson: any product of the past can be heritage. Inspired by this film, protestors against the authorities in the US, China, and other places have displayed their messages on gun controls, health care, as well as domestic violence and educational policies that discriminate against homosexuals in the style of the three billboards. Those successive acts suggest that the film itself can be heritage for those who discover something that can be useful for the present and future generations. If UNESCO correctly understands heritage as a social process rather than an immutable object, it needs to be more careful about the sociopolitical impact of what it does under the name of heritage.

\section{REFERENCES}

Ara, K. (2015, December). Shukinpei mo shinjinai daigyakusatsu wo yurushita gaimhusho no taizai [A serious crime of the Ministry of Foreign Affairs that allows the 'massacre' that even Xi Jinping does not believe]. Seiron, 132-139.

DeMeritt, J.H.R. (2012). International organizations and government killing: Does naming and shaming save lives? International Interactions, 38(5), 597-621.

Duedahl, P. (2016). A history of UNESCO: Global actions and impacts. Houndmills, Basingstoke, Hampshire and New York: Palgrave Macmillan. 
Flood, A. (2018, September 19). George Orwell archives added to Unesco Memory of the World register. The Guardian. Retrieved from https://www.theguardian.com/books/2018/sep/19/georgeorwell-archives-added-to-unesco-memory-of-the-world-register Friman, H.R. (2015). The Politics of leverage in international relations: name, shame, and sanction. Houndmills, Basingstoke, Hampshire and New York: Palgrave Macmillan.

Fujioka, N. (2015). Toroku shiryo chugokuban anne no nikki jitai ga daigyakusatu fuzai no shoko da [Chinese version of Anne's dairy itself is the evidence that the great massacre did not happen]. Seiron, 124-131.

Harvey, D.R. (2007). UNESCO's Memory of the World programme. Library Trends, 56(1), 259-274.

Hase, H. (2015). Speech at the $38^{\text {th }}$ session. General Conference of UNESCO. Retrieved from https://www.unesco.emb-japan.go.jp/ pdf/SpeechHase_Eng38GC2015.pdf

Houdek, M. (2016). The rhetorical force of 'global archival memory': (Re)situating archives along the global memoryscape. Journal of International and Intercultural Communication, 9(3), 204-221.

House of Councillors of Japan. (2016). Minutes of the meeting of the Committee of Foreign Policy and Defense, No. 2, October 20. Retrieved from http:/ / kokkai.ndl.go.jp/SENTAKU/sangiin/192/ 0059/19210200059002a.html

Logan, W., \& Reeves, K. (2009). Places of pain and shame: Dealing with 'Difficult Heritage'. Milton Park, England: Routledge.

Meskell, L. (2018). A future in ruins: UNESCO, world heritage, and the dream of peace. New York: Oxford University Press.

Nakano, R. (2018). Heritage soft power in East Asia's memory contests: Promoting and objecting to dissonant heritage in UNESCO. Journal of Contemporary Eastern Asia, 17(1), 50-67.

Okabe, N. (2017, September 19). Okabe noboru no oshu bunseki [Okabe Noboru's Europe watch]. Sankei. Retrieved from https://www. sankei.com/smp/premium/news/170919/prm1709190002s2.html

Risse, T., Ropp, S.C., \& Sikkink, K. (1999). The power of human rights: International norms and domestic change. New York: Cambridge University Press.

Sakurai, Y. (2016, October 3). Nihon no teki was nihonjin nanoka [Are the enemy of Japanese Japanese?]. Sankei. Retrieved from https://www.sankei.com/premium/news/161003/prm 1610030006-n1.html 
Sankei. (2015a, October 14). Jiminto no "Chugoku ga shinseishita nankin jiken shiryo no yunesuko kiroku isan toroku ni kansuru ketsugi" zenbun [Full texts of 'LDP's resolution on the inscription of China's nominated the documetns of Nanjing incident']. Retrieved from https://www.sankei.com/politics/news/151014/plt151014 0033-n1.html

(2016a, August 19). Rekishisen, Ianfu shiryo [History wars, comfort women documents]. Retrieved from https://www. sankei.com/premium/news/160819/prm1608190004-n1.html

(2016b, November 1). Yunesuko kioku isan, shinsa tomeika e seifukan iinkai secchi wo yobo [UNESCO documentary heritage, Japan's demand on the creation of inter-state committee]. Retrieved from https:/ / www.sankei.com/life/news/161101/lif1611010010n1.html

(2016c, June 8). Shucho, seifu no musaku ga nihon no meiyo wo sokonatteiru [Argument, the lack of governmental policy damages Japanese honor]. Retrieved from https://www.sankei.com/ column/news/160608/clm1606080002-n1.html

(2017, November 4). Shucho, Yunesuko to nihon [Argument, UNESCO and Japan]. Retrieved from https://www.sankei.com/ column/news/171104/clm1711040002-n1.html

. (2019, November 4). Sekai no kioku minaoshi yosei [Demanding the revision of the Memory of the World]. Retrieved from https://www.sankei.com/politics/news/190219/plt 1902190045-n1.html

Seiron (2015, December). Nankin to ochita yunesuko, kokuren [UNESCO and the UN falling with Nanjing]. Seiron.

Sekai (2016, February). Yunesuko sekai kioku isan wo kangaeru [On UNESCO's world documentary heritage]. pp. 225-236.

Smith, L. (2006). Uses of heritage. London and New York: Routledge.

Suga, Y. (2015a, October, 2). Press conference. Prime Minister of Japan and his cabinet. Retrieved from http://www.kantei.go.jp/jp/ tyoukanpress/201510/2_p.html

. (2015b, October 13 ). Press conference. Prime Minister of Japan and his cabinet. Retrieved from http://www.kantei.go.jp/jp/ tyoukanpress/201510/13_p.html

. (2016, September 12). Press conference. Prime Minister of Japan and his cabinet. Retrieved from https://www.kantei.go.jp/jp/ tyoukanpress/201709/12_a.html 
Takahashi, S. (2015, December). Daigyakusatsu toroku [The inscription of great massacre]. Seiron, 118-123.

. (2016). Yunesuko kioku isan to joshi sabetsu teppai iinkai e no seifu hokoku ni kansuru ichikosatsu [A study of register of the Memory of the World and reports of Japanese government to the committee on the elimination of discrimination against women]. Meisei University's Annual Bulletin of the Graduate School of Education, 1, 1-16.

UNESCO. (1945). Constitution of the United Nations Educational, Scientific, and Cultural Organization: Adopted in London on 16 November 1945. London: Preparatory Commission of the UNESCO. (1995). General guidelines to safeguard documentary heritage. CII-95/WS-11. Retrieved from http://unesdoc.unesco.org/ images/0010/001051/105132E.pdf

(2002). General guidelines to safeguard documentary heritage: A revised edition 2002, CII-95/WS-1rev. Retrieved from http:// unesdoc.unesco.org/images/0012/001256/125637e.pdf . (2017). Executive board, 201 EX/5 Part I (H). Retrieved from http:// unesdoc.unesco.org/ulis/cgi-bin/ExtractPDF.pl? catno $=247706 \&$ lang $=e \&$ from $=141 \&$ to $=149 \&$ display $=2 \& \mathrm{ts}=$ 1499006266

University College London. (2016). Nomination form. Retrieved from http:/ / www.unesco.org/new/fileadmin/MULTIMEDIA/ $\mathrm{HQ} / \mathrm{CI} / \mathrm{CI} / \mathrm{pdf} / \mathrm{mow} /$ nomination_forms/uk_orwell_eng.pdf Van Dijk, T.A. (2003). The discourse-knowledge interface. In: G. Weiss \& R. Wodak (Eds.), Critical discourse analysis: Theory and interdisciplinarity (pp. 85-109). Houndmills, Basingstoke, Hampshire and New York: Palgrave Macmillan.

Yamaguchi, T., Nogawa, M., Suzuki, T.M. \& Koyama, E. (2016). Umi wo wataru 'ianfu' mondai [Comfort women' issue goes overseas]. Tokyo: Iwanami.

Zarakol, A. (2010). Ontological (in)security and state denial of historical crimes: Turkey and Japan. International Relations, 24(1), 3-23.

(2011). After defeat: How the East learned to live with the West. Cambridge and New York: Cambridge University Press. 